\title{
Breast Health to Blind Woman: Validation of Accessible Online Course
}

\author{
Aline Tomaz de Carvalho*, Lorita Marlena Freitag Pagliuca, \\ Ana Fátima Carvalho Fernandes \\ Universidade Federal do Ceará, Fortaleza, Brazil \\ Email: ${ }^{*}$ aline.nurse@gmail.com
}

Received 10 December 2014; revised 31 December 2014; accepted 7 January 2015

Copyright (C) 2015 by authors and Scientific Research Publishing Inc.

This work is licensed under the Creative Commons Attribution International License (CC BY).

http://creativecommons.org/licenses/by/4.0/

c) (7) Open Access

\section{Abstract}

This study aimed to build an accessible online course about breast cancer, focusing on early detection. It is a methodological development study based on the construction of the Health Breast Online Course, accessible for blind women. Content assessment with three health professionals was carried out, in a public university of Ceará, in September 2012. Three blind people educators evaluated pedagogical aspects at a specialized school in Fortaleza, Ceará, in October 2012. The content was modified according to the experts' suggestions to simple language, logical sequence and emphasis on breast self-exam. After three stages of evaluation, it was considered fully adequate. Appearance was evaluated as fully adequate, able to arouse interest and to promote inclusive education. Stages of content and pedagogical aspects assessment have been addressed satisfactorily. There are new steps that must be performed for the validation. This study expands horizons for researches in this subject and generates reflection on accessible online health education.

\section{Keywords}

Validation Studies, Educational Technology, Disabled Persons, Nursing, Breast Neoplasms

\section{Introduction}

The magnitude of breast cancer worldwide is recognized for being the second most frequent type of cancer as the most common among women and accounts for twenty-two percent of cases of the disease each year. In 2012, approximately 522,000 deaths of women were affected by this neoplasm worldwide. It becomes the fifth leading cause of cancer mortality in general, which is set as a global public health issue [1].

Despite the effectiveness of control strategies of breast cancer, there are factors that hinder adherence to tests for screening by women, such as advanced age and poor education related to insufficient practice of these early

\footnotetext{
*Corresponding author.
} 
detection actions [2]. Women with disabilities are less likely to be subjected to screening tests and are in a vulnerable condition, therefore, do not always have access to adequate services, which can delay treatment and put them at greater risk [3].

It is estimated that worldwide more than a billion people live with some kind of disability, representing $15 \%$ of world population [4]. They represent the largest minority in the world, and about 80 percent of them live in developing countries [5].

The comprehensive health care for people with disabilities includes improving information mechanisms such as the creation and distribution of accessible educational materials on health. It requires health professionals to have knowledge about disabilities, policies that hold them and about ways to ensure accessibility.

Among various forms of nurse's performance in promoting the health of the blind woman, strategies are adopted to inform them about breast cancer and its early detection. For this, you can make use of information technologies (ICT) such as the Internet, to disseminate knowledge and social inclusion, important tool of support to overcome inequalities and contribute to inclusion.

Forms of education and communication must be built in an accessible format based on the concept of universal design, ensuring the blind woman full ability to obtain resources and use them whenever necessary. Nursing should make use of these new trends for health education. In addition, it is noticed that there are few studies on the area focused on the person's health promotion visually impaired [6]. On the health promotion strategies, nurses can work in the education of blind woman on prevention and control of breast cancer, by the use of online course available.

The objective was to build affordable online education course on breast cancer, with a focus on early detection. The relevance relies on the availability of updated content on the topic, to improve the knowledge of blind women and promote breast health.

\section{Method}

It is a methodological development study based on the construction of online course, accessible for blind women about breast cancer with a focus on early detection of disease. Digital Educational Material Development Model consists of five phases was adopted: Analysis and Planning, Modelling (conceptual, navigation, interface), Implementation, Evaluation and Maintenance, and Distribution [7]. This article describes the stages of evaluation of the content and pedagogical aspects, which belong to the phase of evaluation and maintenance. Data were collected between the months of September and October 2012.

Called Health Breast Online Course, this one was designed to stream content to blind women and seers on breast cancer, with a focus on early detection of the disease. As a means of distribution, we chose to use the SOLAR Online Learning Environment, from the Federal University of Ceará.

It is divided into five classes; the issues Presentation, SOLAR Environment and its tools, Definition of Breast Cancer, Breast Cancer Epidemiology, Breast Cancer Control Strategies and Early Detection of Breast Cancer Routine in the Public Health System (SUS) were addressed. Audio features for image description about breast anatomy and three questionnaires: the Diagnostic Assessment, Self Assessment and Course Evaluation. As interactive activities, there were three discussion forums.

\subsection{Content Assessment}

It was selected convenience sample consisting of content experts, complying with inclusion criteria of having a doctorate, dissertation or thesis on the subject, published works on the subject, minimum practical experience of three years. They were invited to participate through the researcher private email, received invitation letter and after accepted, received content of the lessons in PDF and audio into text format.

It was held in a specific laboratory, which contained the equipment needed for evaluation. The classes in HTML format were exposed by one of the researchers through a projector. Then the same material printed was provided for easier reading and possible corrections. The Content Assessment instrument contemplated objectives, structure, presentation and relevance that were scored according to Likert Scale, namely: 5-fully adequate; 4-partly suitable; 3-Not applicable; 2-partly inappropriate and 1-fully inappropriate. The intern consistency is considered acceptable in front scores is entering 4 or 5.

The reading of the content was held individually. Then the experts showed changes that were discussed and, where mutually agreed and relevant, followed. At the end, the Content Assessment Tool was filled and returned. 
This process was recorded to capture and facilitate further analysis of the data; the speeches were transcribed and categorized according to the topic of the instrument referred.

After the corrections suggested by the experts, the content was returned to the experts to obtain a final report. Only one re-evaluated the material and two reported having contributed enough in the first assessment and justified that the content, after the corrections in the first evaluation was satisfactory.

\subsection{Evaluation of Pedagogical Aspects}

Specialists in pedagogical aspects obeying criteria of being graduated, and accumulate at least three years of experience in the visually impaired education were invited. After accepting, they attended the blind education school in time and previously scheduled date.

The experts accessed the Online Course Breast Health, hosted in the virtual learning environment, using the login and password of the researcher. The access, reading, navigation and evaluation were performed simultaneously. Finally, a specific assessment tool was completed.

The Pedagogical Aspects Assessment instrument contained questions about identification and professional training, online course's contribution to stimulating learning, encouraging autonomy; use of online course as a way to reach bigger number of the population; importance of content for blind people; ability to arouse interest and curiosity and suitability for use in health in distance education for blind people [8] (Oliveira \& Pagliuca, 2013). They were scored according to Likert Scale, namely: 5-Fully appropriate; 4-Partly Suitable; 3-Not applicable; 2-Partly inadequate; 1-Fully inappropriate.

After the evaluation of each item, it was given time to note possible comments and suggestions. Data were organized in tables according to the answers. The questions with at least $80 \%$ agreement among the experts were considered valid. Those who have not reached the minimum percentage have been restructured according to the suggested changes.

The ethical aspects on researches involving human beings were respected, according to the principles of the Declaration of Helsinki. Participants received information on the nature; objectives and risks related to the study and voluntarily signed the Informed Consent Form.

\section{Results}

This chapter is organized into two items, Assessment with specialists in content and Assessment with experts in Special Education. The tables meet the objective evaluations and comments from experts illustrate the results.

\subsection{Assessment with Experts Content}

Three specialists took part in this step, female and doctor's degrees, called C1, C2 and C3. In the first evaluation of the content of the Breast Health Online Course, four topics were classified as fully adequate and two as partially suitable (Table 1 ).

Regarding the capability of the content providing reflection, two experts justified the score with the necessity to closer the women reality; clarify in the text the goals to be reached, and emphasize positive aspects as need to self-care rather than mortality as described in the speech below: Instead of talking about mortality uses: Important Tip: Make your exams regularly. Look for a health unit C1.

Regarding the ability to facilitate learning, all experts scored as partly adequate and their comments were unanimous on the need to use less flowery language.

Concerning the structure and presentation of content, the assessments are described in Table 2.

It was noted the need to adapt the language to the general public, as well as using less technical terms as described in the statements: This term would be nice if the course was geared toward a professional. So, for the layman the terms should be simpler C3. Very flowery language C2. Example: Use high amount of fat tissue in the breast, rather than dense breasts C1. The presentation of SUS is complex and the terms were confused C2.

Regarding the logical sequence of content, there was no agreement among experts. However, only one comment was made and referred to the need for explanation in initial classes of terms used in later lessons as: Explain in class 2 which are preventable risk factors and unavoidable placed in class 3. C3.

There was no agreement among experts in the evaluation of the topics 3.1 and 3.2 and were not given suggestions (Table 3). However, the topic 3.3 which deals with the incentive to change behaviour and attitude was 
Table 1. First stage of the assessment of content experts: Part 1 of the instrument, related to the objectives.

\begin{tabular}{|c|c|c|c|c|c|}
\hline \multirow{2}{*}{ Topic } & \multicolumn{5}{|c|}{ Score/Number of People } \\
\hline & 5 & 4 & 3 & 2 & 1 \\
\hline 1.1 Portrays technology content & 2 & 1 & - & - & - \\
\hline 1.2 Content provides reflection & 1 & 2 & - & - & - \\
\hline 1.3 Provides clarification on the subject & 2 & 1 & - & - & - \\
\hline 1.4 Emphasizes importance of this issue & 2 & 1 & - & - & - \\
\hline $\begin{array}{l}\text { 1.5 Emphasizes importance of content to the } \\
\text { target audience }\end{array}$ & 2 & 1 & - & - & - \\
\hline 1.6 Facilitates learning & - & 3 & - & - & - \\
\hline
\end{tabular}

Table 2. First stage of the assessment of content experts: Part 2 of the instrument, on the structure and presentation.

\begin{tabular}{|c|c|c|c|c|c|}
\hline \multirow{2}{*}{ Topic } & \multicolumn{5}{|c|}{ Score/Number of People } \\
\hline & 5 & 4 & 3 & 2 & 1 \\
\hline 2.1 Appropriate for the age proposal & - & 3 & - & - & - \\
\hline 2.2 Suitable for blind women and seers & - & 2 & 1 & - & - \\
\hline 2.3 Scientifically correct information & 2 & 1 & - & - & - \\
\hline 2.4 Absent of discrimination or prejudice & 1 & 2 & - & - & - \\
\hline 2.5 Language appropriate for the target audience & 2 & 1 & - & - & - \\
\hline 2.6 Clear information and understandable terms & - & 1 & - & 2 & - \\
\hline
\end{tabular}

Table 3. First stage of the assessment of content experts: Part 3 of the instrument, on the structure and presentation.

\begin{tabular}{cccc}
\hline Topic & & & Score/Number of People \\
\cline { 2 - 4 } & 5 & 4 & 3 \\
3.1 Suitable for health education & 1 & 1 & 1 \\
3.2 Portrays issues needed to clarify & 1 & 1 & - \\
3.3 Encourages change in behaviour and attitude & - & 3 & - \\
\hline
\end{tabular}

assessed as partly adequate by the three experts, with the following comment: The text intends only to inform and achieve some attitude towards breast cancer. It is not proposed to change attitude, which is something more complex. C2.

In the second stage the specialist C3 participated and evaluated topics that had not obtained the maximum score. That is, Content provides reflection, Appropriate to the age proposal, Suitable for blind women and seers, Absent from discrimination or prejudice was assessed as fully adequate. On the other hand, Facilitates learning and Appropriate language for the target audience, were score as Partly Adequate and justified by the permanence of some flowery terms. Clear information and understandable terms were also scored as Partly Adequate and justified the use of three different descriptions used to healthy lifestyle habits. After the third sending of material to review the topics from all parts of the instrument were completely appropriate.

\subsection{Assessment of Pedagogical Aspects}

Three specialists, female, called P1, P2 and P3 took part. During the process of navigating the SOLAR and reading the contents relevant suggestions were observed, noted comments and obeyed.

The Breast Health Online Course Objectives were evaluated according to Table 4. 
Regarding the Structure and Presentation Breast Health Online Course, experts evaluated in accordance with Table 5 .

From this assessment the following comments emerged: The course has very attractive language and design, which brings us to the curiosity of knowing more and more about it P1, P2. Although the content is about breast health, spouses also well understand this issue and should be included in the educational process P1. The course will be important for all women P1, P2, P3. This is something new and very important for blind women P1.

\section{Discussion}

The evaluation by the judges of contents happens completely, and solid contributions were obtained for the material to make available updated content, correct and proper language for the target population. Convoluted terms were modified to more colloquial language, which is recommended for both the education of blind people, such as online courses. The text written in a simple and dialogic way encourages the student to understand himself in this process of learning, in which he participates as a subject of knowledge production [9].

Terms like protuberance and thoracic cage, were modified to nipple and chest, to make reading or audio listening understandable without harming content. Long texts were reduced to make more pleasant and less tiring reading. Questions inserted in the questionnaires of the course, which answers were multiple choices, were restructured to simpler language and to yes/no answers. The Health Breast Online Course does not intend to train specialists in the subject, but arouse the interest on it and expand knowledge on the subject to future change of behaviour regarding breast cancer.

Another suggestion of the experts was to increase the reflection on the importance of Breast Self-Exam (AEM/BSE). All agreed on the importance of a change in women's attitude towards their body and their health through the practice of BSE. In countries where resources for screening tests such as mammography are scarce, or places where there are trained professionals for the clinical examination of the breasts, the BSE is recommended as early detection test and should be performed monthly by the woman, as in Taiwan, China and countries in Africa and Iran [10]-[12]. Studies showed that women who performed BSE noticed its benefits; fewer barriers identified and recognized their self-efficacy in performing the exam, far more than women who did not perform BSE.

Regarding risk factors for breast cancer, it is essential its elucidation for women in an attempt to break with

Table 4. Assessment of experts in pedagogical aspects: Part 1 of the instrument, referring to objectives.

\begin{tabular}{|c|c|c|c|c|c|}
\hline \multirow{2}{*}{ Topic } & \multicolumn{5}{|c|}{ Score/Number of People } \\
\hline & 5 & 4 & 3 & 2 & 1 \\
\hline 1.1 Contributes and stimulates learning & 3 & - & - & - & - \\
\hline $\begin{array}{l}\text { 1.2 Encourages autonomy for being } \\
\text { self-instructional }\end{array}$ & 3 & - & - & - & - \\
\hline $\begin{array}{l}\text { 1.3 Corresponds to the level of knowledge of the } \\
\text { target audience }\end{array}$ & 3 & - & - & - & - \\
\hline 1.4 Arises interest and curiosity & 3 & - & - & - & - \\
\hline $\begin{array}{l}\text { 1.5 Emphasizes the importance of content to the } \\
\text { target audience. }\end{array}$ & 3 & - & - & - & - \\
\hline
\end{tabular}

Table 5. The expert assessment in pedagogical aspects: Part 2 of the instrument, on the structure and presentation.

\begin{tabular}{ccccc}
\hline Topic & & & Score/Number of People \\
\cline { 2 - 4 } & 5 & 4 & - \\
2.1 Adapted to the target audience & 3 & - & - \\
2.2 Appropriate to the age group & 3 & - & - \\
2.3 Free from discrimination or prejudice. & 3 & - & - \\
2.4 Appropriate form and presentation & 3 & -
\end{tabular}


false conceptions existing in society as to the genesis of breast cancer. Myths, incomplete or erroneous information is still persistent in the knowledge of blind women on the development of the disease, suggesting that the risk factors are poorly treated in education actions in this population health [13].

The contributions done by content experts turned predominantly for the best adaptation of the language of educational material, as well as for blind women can, through this material, know about the subject and reflect on their breast health. This becomes relevant in the construction of educational materials on health as this represent an attempt to interfere in the process and should be developed to inform decision-making process [14].

The peer review of pedagogical aspects is presented as an apparent validation stage, where professionals with proven experience in the education of blind people, verify that the educational material fits for the education of these people. This is important because of its experience with the target population, with their educational needs and educational models adapted for the visually impaired.

Experts have knowledge about learning models, teaching techniques, teaching, low vision, Braille, blindness, vision aids and computer and link areas of knowledge. In general the participation of these professionals in society is important not only for students but also for patients, to health professionals, family and society, as they are also responsible for the social inclusion of the visually handicapped [15].

At this stage it was shown that the material is fully suitable for also instruct able-bodied, with an intermediate level of education, as well as other family members and presents itself with favourable conditions for inclusive education. This is strengthened before the concept of inclusion that applies to all who are temporarily or permanently disabled, disadvantaged, encouraging them to interact with independence and dignity in their realm [16].

As passed the reading by the judges of appearance, although they had minimal prior knowledge about the subject, personal questions about breast health emerged and a clear interest in theme was highlighted. The judges have verbalized that the course presents relevant content and simple and clear language. There was an enjoyable sequence and it encourages the student to continue in all content, believe that awakening curiosity.

Health education should be built in an accessible format, so that all people have access to health information. For this, the use of inclusive education by the application of ICT must be able to the inclusion of students with special educational needs through the observance of accessibility criteria [17]. Therefore it is relevant to an interdisciplinary action in building inclusive online courses, as each professional plays an important role in the construction and evaluation of these educational materials.

The presentation of the Breast Health Online Course in digital media, with contrasting colors, size of suitable letter, image description and presentation of breast anatomy image description audio were positively evaluated by the experts. Navigation made it simple which favors the autonomy of the student. The number of pages was considered sufficient as well as the size of the questionnaires.

The number of websites and the amount of information contained on the Internet has increased significantly, making this means of communication as a fundamental tool for the blind and seers [18]. It is increasingly significant the number of visually impaired people using online education. However, it can become a frustrating and daunting task, if the accessibility criteria are not respected.

The adaptation of technological materials, according to principles of universal design, offers blind people independence, interaction opportunity with others and new forms of learning [19].

Describing images, using simple and short texts, obeying logic sequences may promote the learning of both blind people and seers [20].

Evaluating digital educational materials in an accessible online course format, such as health education tool is challenging and offers the prospect of including blind people in an environment where you can enjoy and interact equally with students without disabilities. In the inclusive education perspective, which is part of social inclusion, the proposed course should be an affordable source of learning also for people without disabilities, it can be encouraged to learn, interact, respect and live with diversity [21].

\section{Conclusions}

As stages of development of the Breast Health Online Course, the stages of assessing the content and pedagogical aspects have been addressed satisfactorily. In the assessment of content, suggestions were accepted, corrections done, being the content validated by experts. As for the educational aspects, the Breast Health Online Course was considered as fully appropriate educational materials to educate blind women.

There are new stages that must be performed to validate the Breast Health Online Course. The limitation of 
this study is the non-statistically significant population. This study broadens the horizons for researches on this topic as well as for reflection as the large amount of online educational materials that have been developed without regard to accessibility.

\section{Acknowledgements}

This study was made possible through a grant from the Coordination of Improvement of Higher Education Personnel (CAPES).

\section{References}

[1] World Health Organization (WHO) (2013) Cancer. Geneva. http://www.who.int/cancer/en/

[2] Lee, K., et al. (2010) Factors Associated with Use of Breast Cancer Screening Services by Women Aged $\geq 40$ Years in Korea: The Third Korea National Health and Nutrition Examination Survey 2005 (KNHANES III). BMC Cancer, 10, 144. http://www.biomedcentral.com/1471-2407/10/144 http://dx.doi.org/10.1186/1471-2407-10-144

[3] Kung, P.T., Tsai, W.C. and Chiou, S.J. (2012) The Assessment of the Likelihood of Mammography Usage with Relevant Factors among Women with Disabilities. Research in Developmental Disabilities, 33, 136-143.

http://www.sciencedirect.com/science/article/pii/S0891422211003350 http://dx.doi.org/10.1016/j.ridd.2011.08.032

[4] World Health Organization (2011) World Report on Disability. http://www.who.int/cancer/en/

[5] United Nations (2012) Factsheet on Persons with Disabilities. http://www.un.org/disabilities/default.asp?id=18

[6] Cezario, K.G., et al. (2010) Promoção da saúde e deficiência visual: Produção das pós-graduaçõesbrasileiras. Rev Rene, 11, 187-196. http://www.revistarene.ufc.br/revista/index.php/revista/article/view/388/pdf

[7] Falkembach, G.A.M. (2005) Concepção e Desenvolvimento de Material Educativo Digital. Renote, 3, 1-15. http://seer.ufrgs.br/renote/article/view/13742/7970

[8] Oliveira, P.M.P. and Pagliuca, L.M.F. (2013) Assessment of an Educational Technology in the String Literature about Breastfeeding. Revista da Escola de Enfermagem da USP, 47, 205-212. http://www.scielo.br/pdf/reeusp/v47n1/a26v47n1.pdf http://dx.doi.org/10.1590/S0080-62342013000100026

[9] Ke, F., Chávez, A.F., Causarano, P.L. and Causarano, A. (2011) Identity Presence and Knowledge Building: Joint Emergence in Online Learning Environments? International Journal of Computer-Supported Collaborative Learning, 6, 349-370. http://link.springer.com/article/10.1007\%2Fs11412-011-9114-z\#page-1

[10] Akhigbe, A.O. and Omuemu, V.O. (2009) Knowledge, Attitudes and Practice of Breast Cancer Screening among Female Health Workers in a Nigerian Urban City. BMC Cancer, 9, 203. http://www.ncbi.nlm.nih.gov/pmc/articles/PMC2709903 http://dx.doi.org/10.1186/1471-2407-9-203

[11] Tavafian, S.S., et al. (2009) Prediction of Breast Self-Examination in a Sample of Iranian Women: An Application of the Health Belief Model. BMC Womens Health, 9, 1-7. http://www.biomedcentral.com/1472-6874/9/37

[12] Yang, R.J., et al. (2010) Motivations and Reasons for Women Attending a Breast Self-Examination Training Program: A Qualitative Study. BMC Womens Health, 10, 23. http://www.biomedcentral.com/1472-6874/10/23

[13] França, I.S.X., et al. (2012) Conhecimento de mulheres com deficiência física sobre câncer mamário e autoexame: Estratégia educativa. Rev Rene, 3, 766-774. http://www.revistarene.ufc.br/revista/index.php/revista/article/view/1071

[14] de Oliveira Gozzo, T., Lopes, R.R., Prado, M.A.S., da Cruz, L.A.P. and de Almeida, A.M. (2012) Informações para aelaboração de um manual educativo destinado às mulheres com câncer de mama. Escola Anna Nery, 16, 306-311. http://www.scielo.br/scielo.php?script=sci_arttext\&pid=S1414-81452012000200014\&lng=en http://dx.doi.org/10.1590/S1414-81452012000200014.

[15] Maruyama, A.T., Sampaio, P.R.S. and Rehder, J.R.L. (2009) Percepção dos professores da rede regular de ensino sobre os problemas visuais e a inclusão de alunos com baixavisão. Revista Brasileira de Oftalmologia, 68, 73-75. http://www.scielo.br/scielo.php?script=sci_arttext\&pid=S0034-72802009000200002\&lng=en http://dx.doi.org/10.1590/S0034-72802009000200002.

[16] Batalla, D.V. (2009) Política Nacional de Educación Especial desde la perspectiva de la educación inclusive brasile-a. Fundamentos en human, 19, 77-89. http://dialnet.unirioja.es/servlet/articulo?codigo=3177586

[17] Dias, C.O., Passerino, L.M. and Gluz, J.C. (2011) Keep an Eye on the Screen: Application Accessibility for Learning Objects for Blind and Limited Vision Students. Interdisciplinary Journal of E-Learning and Learning Objects, 7, 157168. http://www.ijello.org/Volume7/IJELLOv7Contents.pdf 
[18] Carvalho, A.T., Silva, A.R.S., Fernandes, A.F.C. and Pagliuca, L.M.F. (2014) Health Education for the Blind: Evaluation of Accessibility of an Inclusive Online Course. Creative Education, 5, 1559-1566. http://file.scirp.org/Html/11-6302302_50205.htm http://dx.doi.org/10.4236/ce.2014.516172

[19] Sapp, W. (2009) Universal Design: Online Educational Media for Student with Disabilities. Journal of Visual Impairment \& Blindness, 103, 495-499. http://eric.ed.gov/?id=EJ858193

[20] Guercio, A. (2011) Adressing Chalenges in Web Accessibility for the Blind and Visually Impaired. International Journal of Distance Education Technologies, 9, 1-13. http://www.igi-global.com/article/addressing-challenges-web-accessibility-blind/58983

[21] Silva, S. (2012) Acessibilidade Digital em Ambientes Virtuais de Aprendizagem. [periódicona Internet]. Revista Geintec, 2, 245-254. http://www.revistageintec.net/portal/index.php/revista/article/view/48. 
Scientific Research Publishing (SCIRP) is one of the largest Open Access journal publishers. It is currently publishing more than 200 open access, online, peer-reviewed journals covering a wide range of academic disciplines. SCIRP serves the worldwide academic communities and contributes to the progress and application of science with its publication.

Other selected journals from SCIRP are listed as below. Submit your manuscript to us via either submit@scirp.org or Online Submission Portal.
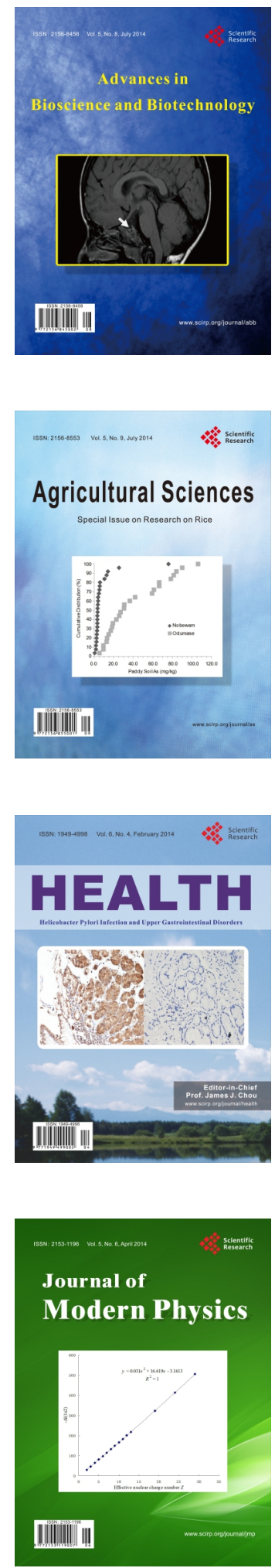
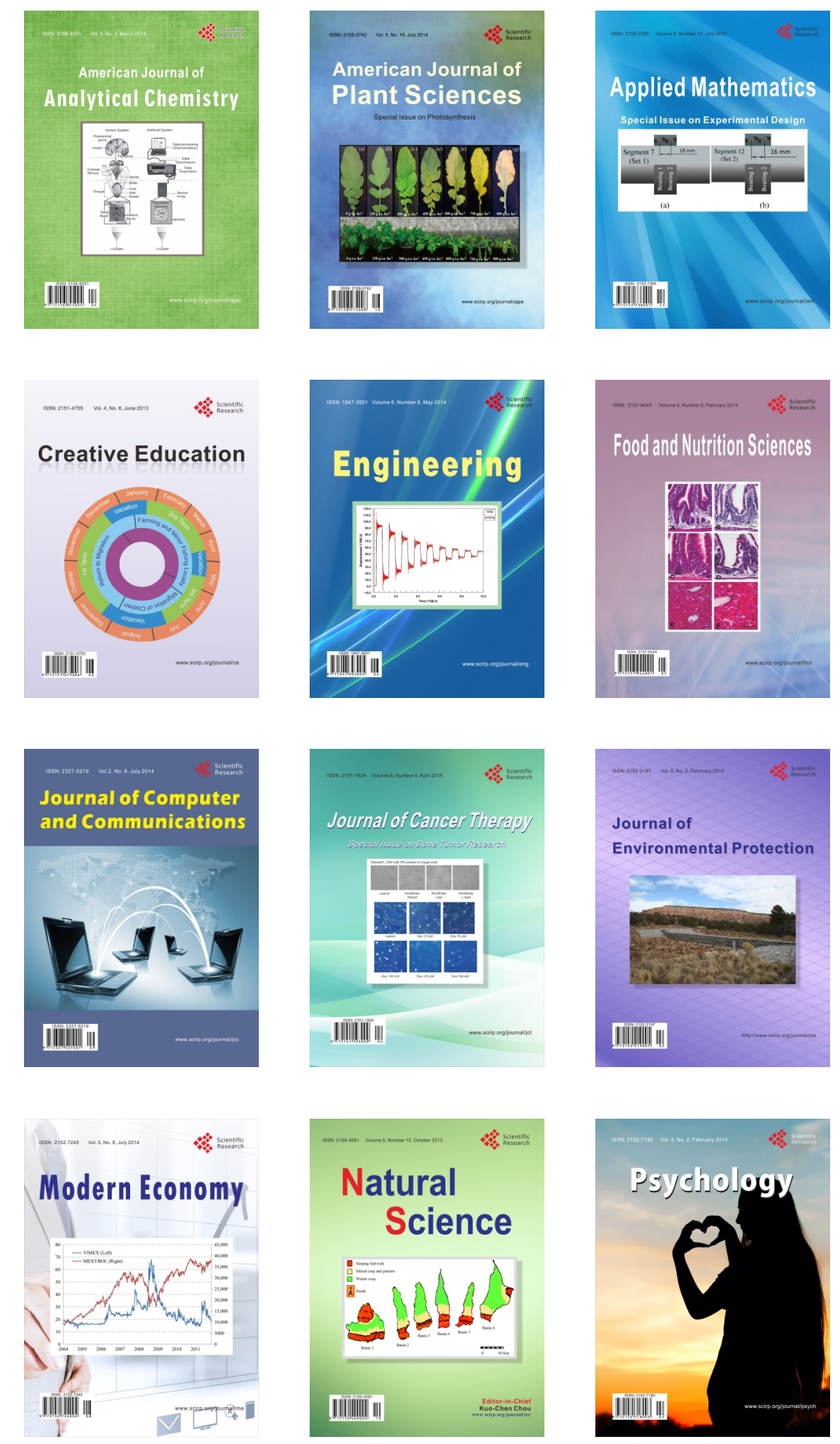